\title{
Tax Reform and Investment: Blessing or Curse?
}

\section{Steven M. Fazzari}

A the Tax Reform Act of 1986 will reduce capital spending incentives in the United States.' Many analysts fear this result.

There is, however, an alternative view. By removing special subsidies for various kinds of investment, tax reform may encourage firms to invest in projects because they have high economic returns, rather than large tax benefits. If economic returns more closely reflect social values than the previous tax subsidies, investments could be better suited under tax reform to produce goods and services that people want and enhance the productivity of the economy. Thus, the recent reform of capital taxation may actually improve econonic welfare, even though it reduces the aggregate capital stock and investment. This paper investigates the welfare implications of the new capital tax system.

Steven M. Fazzari, an assistant professor of economics at Washington University in St. Louis, was a visiting scholar at the Federal Reserve Bank of St. Louis. The author thanks James C. Poletti for research assistance and Chris Varvares for helpful discussion.

'See, for example. Prakken (1986), Henderson (1986), Aaron (1987), the Economic Report of the President (1987) and Fazzan (1987).

\section{THE EFFICIENT ALLOCATION OF CAPITAL RESOURCES}

In many popular discussions of taxes and investment lurks an implicit assumption that more invest ment is always better than less. After all, investment causes the capital stock to expand increases potential output growth and enhances labor productivity. While these outcomes are undoubtedly desirable, the simple view that investment is always beneficial ignores the costs imposed by greater capital accumulation. By investing resources in more productive capital, people forego the opportunity to consume some goods and services. Thus, investment generates opportunity $\operatorname{costs}^{2}$

To evaluate whatever changing levels of investment improve social welfare, one needs a criterion that incorporates both the costs and benefits of changes in

2The opportunity costs associated with investmen may be best illustrated by an extreme case. Suppose all of a society's output were invested in capital goods. Growth would be maximized but there would be no current consumption at all. This perspective emphasizes the irade-offs between investment and consumption. One could asso consider the efficiency of the allocation of total investment among different capital projects; this topic, however, is outside the scope of this article. 
the capital stock. The most widely used criterion that meets this objective is economic efficiency, ${ }^{3}$ A particular level of investment is efficient if the benefits of all projects undertaken exceed their cost while the benefits of investment projects foregone fall short of their costs. Let us consider this concept in more detail.

The benefit gained from a marginal investment has two dimensions: the amount of new output the investment produces and the length of time it takes for this additional output to become available. Consider an investment project that increases output by $Y$ units at the end of its first year of production. Assume that the project depreciates at a constant annual rate $\mathrm{d}<1$, so that it produces $(1-\mathrm{d}) \mathrm{Y}$ units of output at the end of the second year, $(1-d)^{2} Y$ units at the end of the third year, etc. In general, the project will produce $(1-\mathrm{d})^{1-1} Y$ units of additional output at the end of yeart.

Let $P$ represent the market price of the output that individuals are willing to pay for additional units of this good. According to the economic efficiency crim terion, this price represents the current value of a unit of output. Thus, the social value of an investment project in any year will be the quantity of additional output it produces multiplied by the goods' market price.

The concept of time preference implies that for a variety of reasons (impatience, uncertainty and attitude toward risk, for example), individuals would prefer to have goods and services sooner rather than later. Thus, the value of a given bundle of goods is smaller the further in the future it becomes available.

A simple way of expressing this idea formally is to assume that individuals discount the value of output available in the future, relative to the value of current output, at a constant rate $r$, where $r$ is a positive fraction. Thus, if a bundle of consumption goods available today has a value of $\$ 10$, the present value of the same bundle delivered a year from now will be $\$ 10 \%$ $(1+r)$. If it is delivered in two years, it will have a lower present value, $\$ 10 /(1+r)^{2}$. In general, the present value

3Although efficiency is the most widely used welfare criterion, it does not address some significant welfare issues. Most important, the efficiency criterion does not deal with the equity of changes in wealth distributions caused by policy changes.

${ }^{4}$ There are important limitations to the view that the market price measures the value of output because this measure does not incorporate any concept of distributional equity. The efficiency criterion remains meaningful for any given distribution of wealth, but it cannot be used to evaluate the implications of changing wealth distributions. of output that is worth PY at a time tyears in the future is $\mathrm{PY} /(1+r)^{\text {? }}$.

These concepts allow us to construct an expression for the present value ( $V$ ) of an investment project that increases output in each future period $t$ by $(1-d)^{t-1} Y$ units. The output has a constant market price of $P$. The present value is:

$$
V=\sum_{t=1}^{\infty}(1-d)^{1-1} \operatorname{PY}(1+\Gamma)^{-t}
$$

which simplifies to:

$$
V=P Y /(r+d))^{5}
$$

To attain economic efficiency, any project should be undertaken that has a present value exceeding its present cost, the market price of the capital project denoted by $P_{c}$. Thus, efficiency requires investment up to the point where the least-valued project undertaken has a productivity $Y$ that satisfies:

$$
\begin{aligned}
& P_{c}=V=P Y /(r+d), O F \\
& (r+d) P_{c}=P Y .
\end{aligned}
$$

The efficiency condition given by equation 1 has a natural graphical interpretation. Rewrite equation 1 as:

(2) $\quad P Y-d P_{c}=r P_{c}$.

The right side represents the cost of deferring consumption. In figure 1 , this cost rises as the capital stock expands because the more resources that are deferred away from consumption into capital, the greater the premium individuals require to compensate them for their time preference. The left side of equation 2 represents the net output created by an investment project after allowing for the depreciation of capital. In figure 1, this net marginal benefit from the least productive investment falls as the capital stock increases.

$$
\begin{aligned}
& \text { 5This simplification is based on the fact that the geometric series } \\
& \sum_{t=0}^{\infty} \alpha^{\mathrm{t}} \text { is }(1-\alpha)^{-\mathrm{t}} \text {. Thus, } \\
& V=\frac{P Y}{1-d} \sum_{t=1}^{\sum}\left(\frac{1-d}{1+r}\right)^{t}=\frac{P Y}{1-d}\left[\sum_{t=0}^{\infty}\left(\frac{1-d}{1+r}\right)^{t}-1\right] \\
& \quad=\frac{P Y}{1-d}\left[\left(1-\frac{1-d}{1+r}\right)^{-1}-1\right]=\frac{P Y}{1-d} \frac{1-d}{d+r}=P Y /(d+r) .
\end{aligned}
$$




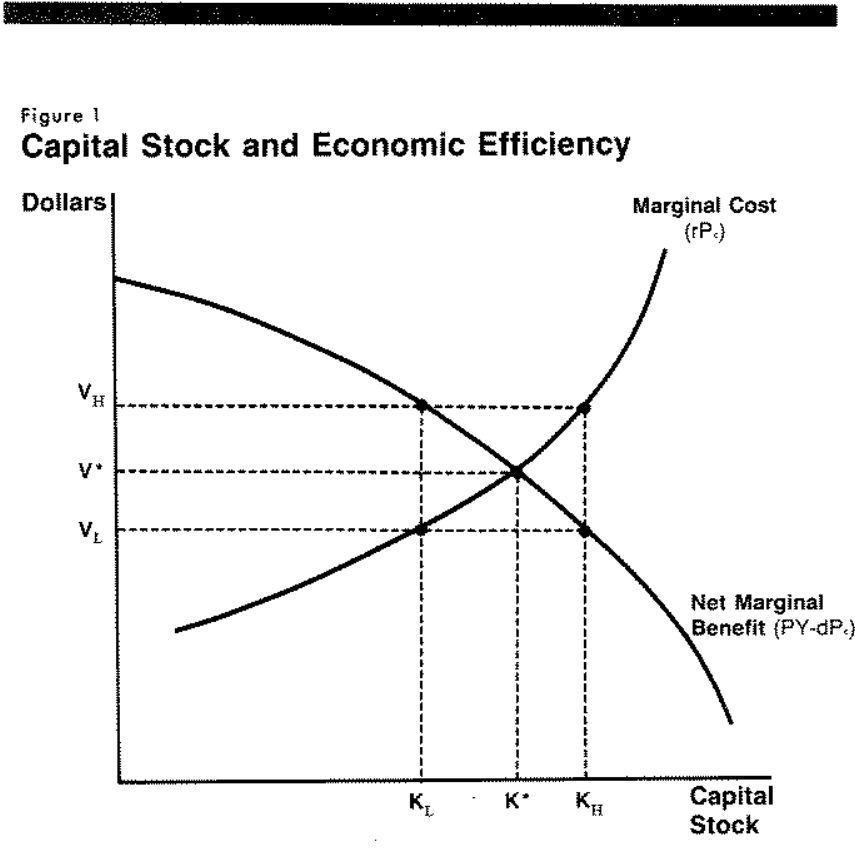

in: earnings foregone by investing funds in fixed capital rather than financial assets. ${ }^{6}$

A firm's capital investment will be profitable if:

$$
\mathrm{PY}>\mathrm{P}_{\mathrm{a}} \mathrm{d}+\mathrm{P}_{\mathrm{r}} \mathrm{i}
$$

where i represents the real rate of interest the firm foregoes by investing in fixed capital. Thus, firms will invest up to the point where

$$
\text { (3) } \quad P Y=P_{c}(d+i) .^{z}
$$

Note that equation 3 looks almost the same as equa tion 1 . They will be the same if the real market rate of interest ( $i$ in equation 3 ) equals individuals' discount rate $(r$ in equation 1$)$. This point will be addressed below.

In spite of their close similarity, it is important to understand the conceptual distinction between equations 1 and 3 . Equation 1 defines a welfare standard for investment and the capital stock according to the efficiency criterion. On the other hand, equation 2 describes the level of investment profit-maximizing firms will undertake in the market.

Much economic analysis has been devoted to understanding the conditions under which economic efficiency will be attained by the market. To obtain this result for the market analyzed here, the interest rate must equal individuals' discount rate. The real interest rate represents the opportunity cost to firms of borrowing funds for capital investment. It also is the return to savers who give up the chance to consume today by lending, either directly or through financial intermediaries.

Suppose individuals decide that they want to consume more today. They reduce their saving, decreasing the supply of funds flowing into credit markets, driving up interest rates. This continues until individuals are satisfied with the current level of saving at the prevailing market interest rate. Thus, the interest rate measures individuals' discount rate at the margin, the premium they require to exchange some consumption now for consumption in the future in the absence of personal taxes on interest income. Under these circumstances, the interest rate equals the discount rate $(i=r)$, and equations 1 and 3 determine identical levels of the capital stock. That is, firms will have profit

${ }^{8}$ For a further discussion of the revenues and costs that determine the profitability of investment, see Fazzari (1987).

7 This condition is equivalent to the maximization of net present value, under the assumptions made here. 1 have also assumed that the firm is a price-taker, in both input and output markets. 
incentives to invest in capital just up to the efficient level."

\section{EFFICIENGY AND NEU'TRAL TAXATION}

The main result of the previous section suggests that the market outcome of firms' independent, selfinterested investment choices leads to an efficient capital stock. The analysis that led to this result, however, ignores the effect of corporate taxes on investment incentives. This section introduces the influences of corporate taxes; it provides a theoretical basis for evaluating the implications of tax reform for efficient capital investment.

As a general mule, taxes change the economic incentives faced by firms. In the case of the corporate income tax, however, it is possible, at least in theory, to structure the tax so that capital investment decisions do not change. Rewriting equation 3, we see that firms will invest up to the point where the economic profits from a marginal investment project equal zero:

$$
\text { (4) } \quad 0=P Y-P_{c}(i+d) \text {. }
$$

The right side of equation 4 represents the economic profits from a marginal investment. Suppose these profits are taxed at a rate $T$. Then firms will invest up to the point where after-tax profits from a marginal investment are zero,

$$
\begin{aligned}
& 0=(1-\tau)\left[P Y-P_{r}(i+d)\right], \text { or } \\
& (1-\tau) P Y=(1-\tau)\left[P_{r}(i+d)\right]
\end{aligned}
$$

The level of capital investment that satisfies equation 4 will also satisfy 5 ; the same actions that maximize 100 percent of profits will maximize 80 percent, 60 percent, or any non-zero proportion of profits. In this case, the corporate tax rate affects the portion of a firm's profits that go to the government, but it does not

\footnotetext{
睢e result that unrestricted market interaction leads to efficient outcomes is often used to argue for the normative position that market results are socially desirable. This conclusion, however, is limited in general. Again, the idea that the willingness of individuals to save at the margin represents the social discount rate takes the distribution of wealth as given. The efficient capital stock level would likely change for different wealth distributions. Also, investment may have external social costs or benefits not recognized by the private firms that make investment decisions. Thus, private market investment incentives might differ from social incentives. Finally, this analysis applies only to general economic equilibrium with full utitization of resources. Existence of involuntary unemployment or idle capacity would change the structure of the analysis. Despite these qualifications, efficiency analysis is widely regarded as relevant to evaluate the long-term impact of the tax system.
}

affect the firm's incentives to invest efficiently. ${ }^{9}$

Economists call this kind of tax neutral. A neutral tax does not change the allocation of economic re sources. The key to neutral taxation in this context is that all revenues are taxed while all economic expenses are fully deductible. ${ }^{10}$ This result is clear in theory, but difficult to implement in practice, as we will now discuss.

\section{U.S. CORPORATE TAXATION}

The U.S. corporate tax system is not nearly as simple as the tax analyzed above. In general, it is not neutral. The next section summarizes the effect of the tax code on the cost of capital. Then, three important nonneutral aspects of U.S. tax law are discussed; tax de preciation schedules, the investment tax credit, and the deductions allowed for the opportunity cost of invested capital. Some non-neutralities arising from personal taxes are considered later.

\section{The Cost of Capital in the U.S. Tax System}

The efficient capital stock condition given by equation 5 under neutral taxation assumes that the economic costs of capital are fully deductible from taxable income. For a variety of reasons, however, the U.S. tax code does not allow deductions based strictly on. economic costs. This introduces a number of nonneutral aspects into the tax code. To understand the source of these non-neutralities, we must compare the determination of capital investment under the U.S. tax law with the efficiency standard of a neutral tax given by equation 5 .

Let $k$ represent the investment tax credit rate, $z$ the present value of a one-dollar tax deduction for depreciation, and $L$ the proportion of a marginal investment financed with debt (the debt leverage ratio). Suppose the expected inflation rate is $\pi_{\mathrm{e}}$. Profit-maximizing firms will invest up to the point where the least-valued

\footnotetext{
9This result assumes that the firm is indifferent between internal and external sources of finance. If this is not the case, investment may be affected by reduced cash flow caused by higher corporate taxes, even if the tax is neutral in the sense discussed in the text. See Fazzari (1987) and Fazzari and Athey (1987) for further discussion.

${ }^{10}$ Economic expenses include all the opportunity costs of buying and using capital. They may difer in important respects from accounting costs used by firms in their financial statements. Interest foregone on shareholders' equity, for example, represents an economic opportunity cost but is not deducted from the firm's accounting profit.
} 
unit of capital purchased satisfies,

$$
(1-\tau) P Y=P_{c}(1-k-\tau z)\left[i+d-\tau L\left(i+\pi_{e}\right)\right] .^{11}
$$

The left side of equation 6 is the after-tax benefit gained from investment, as presented earlier. The term $P_{c}(1-k-\tau z)$ on the fight side represents the fact that each dollar spent on investment generates an investment tax credit of $k$ and a depreciation deduction with a present value of $z$.

The other change in equation 6 relative to the neutral tax case in equation 5 is that only explicit interest costs are deductible from taxable income. Thus, if the firm finances investment with debt, the explicit interest expense can be deducted from taxable income, but the opportunity cost of interest foregone on reinvested intemal funds or proceeds from new equity issues cannot be deducted. Furthermore, because nominal interest is deducted, changes in the inflation rate will affect the value of the interest tax deduction, to the extent that markets anticipate inflation in the nominal interest rate.

As equation 6 indicates, the U.S. tax system may introduce non-neutralities. The complicated expression on the right side of equation 6 reduces to the efficient neutral tax given by equation 5 only under special circumstances. We shall now consider this point in greater detail.

\section{Depreciation Allowances}

In the neutral tax equation 5 , economic depreciation is deducted from taxable income in every period. In equation 6 , the present value of depreciation allowances $(z)$ is reated as a lump-sum deduction that reduces the after-tax price of capital goods up front. The two approaches will lead to equivalent results, however, if the depreciation schedule underlying the calculation of $z$ is the same as economic depreciation.

To find the present value of depreciation allowances that leads to neutral taxation, suppose that there is no investment tax credit $(k=0)$, the firm finances marginal investment with debt alone $(L=1)$ and expected inflation is zero $\left(\pi_{e}=0\right)$. Then equation 6 reduces to:

$$
(1-\tau) \text { PY }=P_{0}(1-\tau Z)[(1-\tau) i+d) .
$$

\footnotetext{
"The original reference for the form of the cost of capital given in equation 6 is Hall and Jorgenson (1967). Further references and a more-detailed explanation of the components of equation $6 \mathrm{can}$ be tound in Fazzari (1987).
}

To make equation 7 equivalent to the condition describing efficient investment from equation 5 , the marginal cost of a new unit of capital must be the same in each case. This implies that the right side of equation 4 equals the right side of equation 6 :

$$
(1-\tau) P_{k}(i+d)=P_{E}(1-\tau Z)[(1-\tau) i+d]
$$

This equation can be solved for the efficient present value of depreciation allowances $\left(z^{*}\right)$, that is,

(8) $\left.\mathrm{z}^{*}=\mathrm{d} /[(1-\tau) \mathbf{i}+\mathrm{d}]\right]^{12}$

Intuitively, $z^{*}$ is the present value of a perpetual depreciation flow $\mathrm{d}$ per dollar of investment. The discount rate consists of the afterwtax real interest rate plus the depreciation rate. The latter term appears because the amount of depreciation declines as the asset deteriorates.

The present values of depreciation schedules prescribed by the tax code can be compared with the efficient benchmark given by $z^{*}$. The first column of table 1 gives the efficient present value under the old and new tax laws. ${ }^{13}$ The efficient present value changed after tax reform because the corporate tax rate fell from 46 percent to 34 percent.

The present value of actual depreciation allowances prescribed by the tax code are presented in the second, third and fourth columns of table 1, again for the old and new tax laws. ${ }^{t 4}$ Expected inflation plays an important role here. Neither the old nor the new tax law indexes depreciation deductions for inflation. Assuming that higher expected inflation increases nomi-

requivalently, $z^{*}$ can be derived by computing the present value of economic depreciation deductions discounted at the ater-tax real rate of return $(1-\tau)$. This analysis is complicated if one explicity considers the differential tax treatment of dividends and capital gains where corporate income is distributed to sharehotders. See Auerbach (1983) for further discussion.

toThe efficient present value $\left(z^{*}\right)$ calculations in table 1 assume a real discount rate of 3 percent, before taxes. The economic depreciation rates for autos and ight trucks, office computing and accounting equipment, and communications equipment were estimated by Gravelle (1982) as $.33, .27$ and .12 , respectively. The average economic depreciation rates for equipment and business structures were .14 and .06 from the Washington University Macro Model maintained by Laurence $H$. Meyer and Associates, Ltd.

${ }^{14}$ See Ott (1984) and Fazzari (1987) for a discussion of how these present values are computed and the datails of the lax depreciation schedules. These calculations do not account for the fact that the depreciable base for an asset eligible for the investment tax credit was reduced by one-half of the credit, under the old tax law. This simplification is made to focus on the fect of changing the depreciation schedules alone. It is formally equivalent and conceptually simpler to think of the reduction in the depreciation base due to the investment tax credit as a reduction in the value of the credit rather than in the present value of depreciation deductions. 


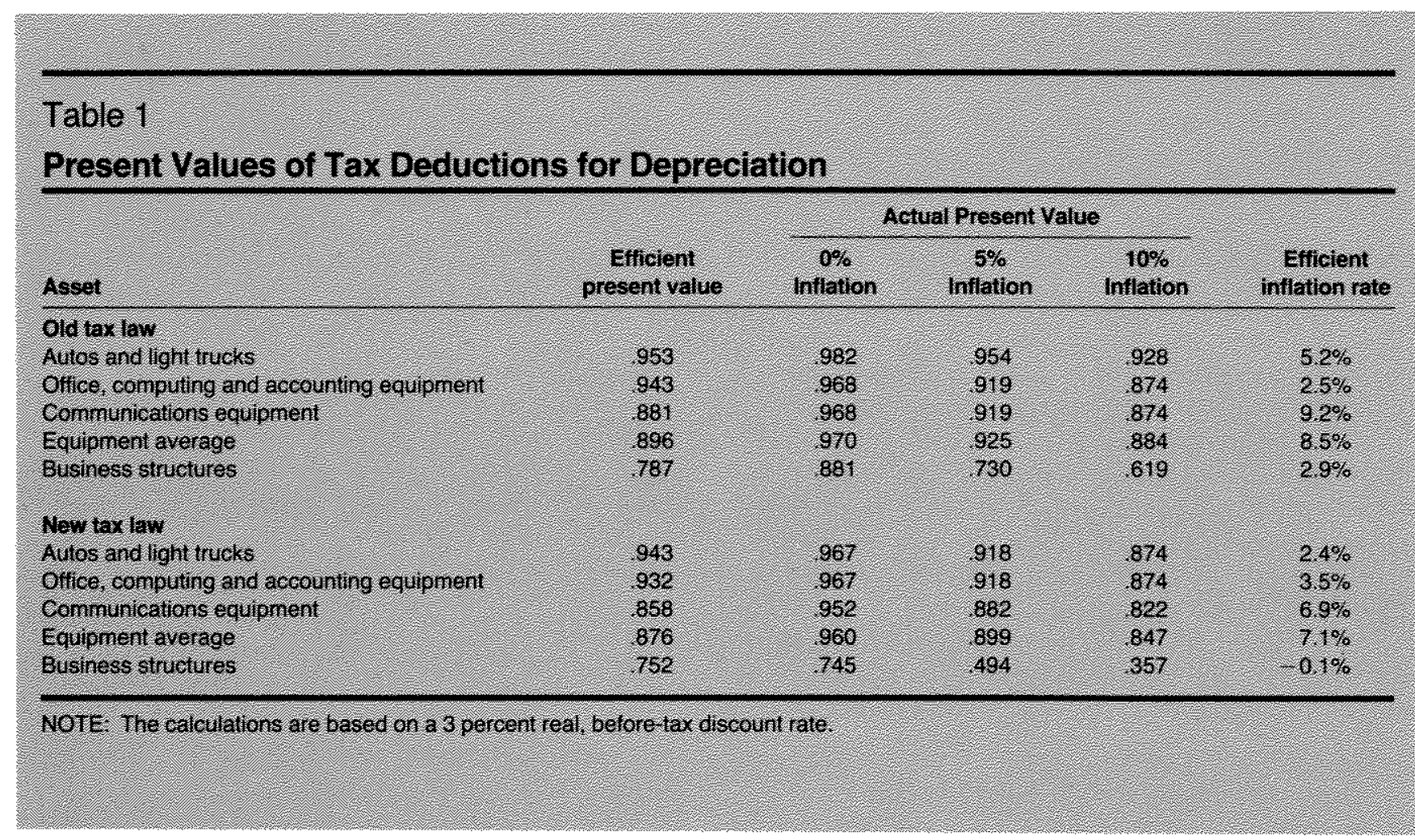

nal interest rates, the present value of a fixed, nominal depreciation flow decreases with rising expected in flation, as shown in table $1^{35}$

With no expected inflation and nominal interest rates equal to real rates, the tax depreciation schedules generally lead to more generous present values than the efficient present value. Thus, the rapid writeoffs of capital goods allowed by the tax code subsidize investment in the absence of inflation. Although the new tax law reduces this subsidy somewhat, the differential still remains.

As expected inflation rises, however, the present values of actual depreciation allowances decline and approach the efficient level. The final column of table 1 gives the expected inflation rate at which the present value of the depreciation deduction allowable for tax purposes equals the efficient level. Under the old tax law, equipment deductions, on average, would have

\footnotetext{
${ }^{15}$ For the calculations in table 1 , the before-tax nominal discount rate is assumed to rise by one percentage point for each percentagepoint increase in the expected inflation rate. A number of economists have argued that nominal interest rates must increase by more than the rise in expected inflation to maintain real returns constant because of personal taxes levied on nominal interest income. See Darby (1975) and Feldstein (1976), for example. If this is the case, the present values of depreciation allowances will decline more than the figures in table 1 indicate when expected inflation rises.
}

been efficient with an expected inflation rate of 8.5 percent. After tax reform, this declined to 7.1 percent. ${ }^{16}$

The results for business structures are somewhat different. The rapid structure depreciation allowed under the old tax law led to a substantial subsidy at zero expected inflation. Because of its slow depreciation, however, the present value of nominal depreciam tion allowances for structures is especially sensitive to any changes in nominal interest rates caused by rising expected inflation. Thus, under the old tax law, the accelerated structures deduction was efficient at a moderate 3.1 percent expected inflation rate.

Tax reform sharply reduced the present value of structures depreciation; it incteased the tax service life from 19 to 31.5 years and replaced an accelerated depreciation schedule with a straight-line schedule. As table 1 shows, this pushes depreciation allowances for business structures to the efficient level at an expected inflation rate close to zero. Even at moderate levels of expected inflation, however, the slow write-off mandated by the new tax law causes a substantial

\footnotetext{
${ }^{16}$ This result is sensitive to the assumption made about the real before-tax discount rate. If this rate increases from 3 percent to 5 percent, the efficient expected inflation rate for the equipment average rises from 7.1 percent to 12.0 percent.
} 
disincentive for structures investment relative to the efficient level.

\section{The Investment Tax Credit}

The depreciation deductions allowed in the tax code correspond to one as pect of the economic cost of using capital. In a neutral tax system, the economic value of these costs should be deducted from taxable income. Inefficiency arises from depreciation deductions only to the extent that the tax depreciation schedules are more or less generous than economic depreciation.

The investment tax credit, on the other hand, represenis a direct subsidy to investment. It does not correspond to any aspect of the economic cost of capital. By itself, the investment tax credit provides incentives for firms to purchase more of the eligible assets than the efficiency criterion would dictate. The repeal of the credit in the new tax law moves the tax system closer to neutrality.

The investment tax credit applied to only a subset of capital assets. Thus, the subsidy not only distorted the amount of investment, but also the composition of investment. A detailed analysis of this issue lies outsicie the scope of this paper, but efficiency gains from the repeal of the credit may result from a more effective allocation of investment among different assets and activities. Furthermore, inefficient investment that took place as a result of the subsidy competed for scarce funds and raised the interest rate. This could have crowded out other efficient projects that may have been undertaken in the absence of the subsidy. ${ }^{17}$

Of course, given other distortions in capital taxation, some kind of subsidy may be appropriate to offset the disincentives to investment arising from other aspects of the tax system. As the previous analysis showed, the equipment assets eligible for the investment tax credit generally benefit from rapid depreciation deduction subsidies at low inflation rates even with the changes due to tax reform. Thus, the investment tax credit is not needed in the current environment to offset the distortions caused by tax depreciation schedules. The credit, however, may offset another distorting aspect of the tax code: firms' inability to deduct the full opportunity cost of funds tied up in capital investment.

\footnotetext{
17The author thanks Milton Friedman for comments on an earlier paper that emphasized these points.
}

\section{Debt Financing and Capital Cost Deductions}

In the neutral tax system represented by equation 5 , the opportunity cost of capital given by the real interest rate (i) is fully deductible from taxable income. It does not matter whether the interest expense involves explicit payments to debt holders or implicit opportunity costs of foregone interest earnings by equity holders. ${ }^{.7}$ The tax law, however, allows deduction of explicit interest expense, but does not allow deduction of interest foregone when investment is financed through intemal cash flow or new equity.

To the extent that new capital spending is not completely debt-financed, the after-tax cost of capital rises and investment falls relative to the efficient level. This effect is reflected in equation 6 by the fact that the deduction for interest expense is multiplied by the marginal proportion of investment financed by debt (L). This introduces an important non-neutrality into the tax system.

At a zero inflation. rate, this effect alone gives firms an incentive to employ less than the efficient level of capital. But inflation mitigates this distortion. The economic cost of capital depends on the real interest rate. The tax code, however, allows firms to deduct nominal interest expense. As expected inflation and nominal interest rates rise, therefore, the real value of tax deductions for interest expenses increases.

At a sufficiently high inflation rate, the tax benefit from deductions for nominal interest will offset the increase in the after-tax cost of capital arising because interest foregone on internal financing cannot be deducted from taxable income. One can solve for the expected inflation rate that leads to this efficient result $\left(\pi^{*}\right)$ by equating the deductions for interest expense in the neutral tax system from equation 5 with the de. duction in the actual tax system from equation 6 :

$$
\tau i=\pi\left(i+\pi^{*}\right)
$$

This gives

(9) $\pi^{*}=\mathrm{i}(1-\mathrm{L}) / \mathrm{L}$.

With a real interest rate of 3 percent and the debt leverage ratio 30 percent, the efficient inflation rate from equation 9 is 7 percent. ${ }^{2}$

\footnotetext{
t8See Fazzari (1987) for a further discussion of debt and equity finance for capital spending.

19The average corporate debt leverage ratio in the second quarter of 1986 was 30.6 percent according to data from the Washington University Macro Model.
} 
Tax reform has a subtle effect on this problem. The new tax code, like the old law, does not allow deductions for interest foregone by shareholders. But the new law eliminates preferential personal tax rates for capital gains income. Thus, corporations will have an incentive to pay out a greater proportion of their income as dividends and finance more new investment with debt. This reduces the efficiency distortion caused by the non-deductibility of foregone interest from internal finance at low inflation rates.

\section{HNVESTMENT NON-NEUTRALITLES FROM PETSONAL TAXES}

The discussion to this point has focused primarily on the corporate tax system. But, ultimately, corporate profits accrue to shareholders who are liable for personal taxes as well. We shall now consider the effect of personal taxes on the firm's incentive to invest in fixed capital.

If personal taxes on all corporate-source income were uniform, they would not directly affect corporate investment decisions because, again, the same actions that maximize 100 percent of profits will maximize any constant proportion of profits. ${ }^{21}$ Personal taxes on corporate income, however, are not uniform. In particular, income from capital gains has been taxed at lower rates than dividend and interest income.

This lower rate provides a rather subtle subsidy for investment. Suppose individual capital gains are taxed at a rate $\tau_{\text {ch }}$ while interest income is taxed at the regular personal rate $\tau_{p}$. If capital markets equate the after-tax rate of return on earnings retained by the corporation with the after-tax interest rate on debt, then:

$$
\left(1-\tau_{\mathrm{cg}}\right)\left(i_{\mathrm{cg}}+\pi_{\mathrm{e}}\right)=\left(1-\tau_{\mathrm{p}}\right)\left(\mathbf{i}+\pi_{\mathrm{e}}\right),
$$

where $i_{c g}$ is the implicit real interest rate on corporate retentions. Thus, as long as:

$$
\begin{aligned}
& \tau_{\mathrm{rg}}<\tau_{\mathrm{p}} \\
& \mathrm{i}_{\mathrm{cg}}+\pi_{\mathrm{i}}=\left(\mathrm{i}+\pi_{\mathrm{e}}\right)\left(1-\tau_{\mathrm{p}}\right) /\left(1-\tau_{\mathrm{cg}}\right)<\left(\mathrm{i}+\pi_{\mathrm{e}}\right) .
\end{aligned}
$$

\footnotetext{
200bt finance is beneficial in the sense that it pushes the economy closer to efficiency at the microeconomic level. On the other hand, higher debt ratios can make the macroeconomic system as a whole less stable. This issue is outside the scope of this paper. For further discussion, see Caskey and Fazzari (1986)

${ }^{2}$ Even uniform personal taxation could have an indirect effect on investment because the tax on the return from saving will reduce individual incentives to defer current consumption. This tends to raise real interest rates and increase the opportunity cost of capital. This issue is considered later in the article.

22This approach follows Henderson (1986), p. 23. It ignores any risk premium required by investors in corporate equity.
}

The favorable treatment of capital gains income leads to a subsidized rate of interest for investment financed with retained earnings.

Let us integrate this effect into the cost of capital formula. As before, assume that the firm finances a fraction $L$ of marginal investments with debt and $1-L$ with retained earnings. The weighted average nominal opportunity cost of funds the firm faces is:

$$
\mathrm{c}=(1-L)\left(\frac{1-\tau_{\mathrm{p}}}{1-T_{\mathrm{g}}}\right)\left(\mathbf{i}+\pi_{\mathrm{e}}\right)+L(1-\tau)\left(\mathbf{i}+\pi_{\mathrm{e}}\right)^{23}
$$

The firm's cost of capital is then:

(11) $P_{\mathrm{e}}(1-\mathrm{k}-\mathrm{Tz})\left(\mathrm{c}-\pi_{\mathrm{e}}+\mathrm{d}\right)$.

Equation 11 reduces to the right side of equation 6 when the personal tax rate on capital gains equals the personal tax rate on regular income $\left(\tau_{\mathrm{cg}}=\tau_{\mathrm{p}}\right)$.

\section{Capital Gains Taxation After Tax Reform}

Tax reform has fundamentally changed the terms of the capital gains subsidy by repealing the 60 percent exclusion for capital gains income. This change, however, does not mean that the personal tax advantages of capital gains income has been removed. Shareholders that receive capital gains income still benefit from the deferral of tax until the time the asset is sold and the capital gain is realized.

The effective tax rate on capital gains income, therefore, depends on the length of time an investor holds an asset. One can compute $T_{\mathrm{cg}}$ as the present value of the tax paid at realization per dollar of capital gain discounted at the individual's after-tax real interest rate:

(12) $\tau_{\mathrm{rg}}=(1-\mu) \tau_{\mathrm{p}} /\left[1+\left(1-\tau_{\mathrm{p}}\right) \mathrm{i}\right]^{\mathrm{H}}$,

where $\mu$ is the proportion of capital gains income excluded from tax and $H$ is the holding period. ${ }^{24}$

\footnotetext{
Equation 10 is based on two simplifying assumptions. First, no marginal investment is financed with new share issues. According to Henderson (1986), new shares account for only 4.9 percent of the U.S. capital spending finance. Second, and more importantly, equa" tion 8 assumes that the earnings from marginal, internally financed investments are completely retained and will be taxed as capital gains. This analysis is complicated by dividends. See Auerbach (1983) for further discussion.

${ }^{24}$ This equation is a simplification. In general, the accrual-equivalent capital gains tax rate depends on the rate of growth of the asset's value and the holding period in a more complicated way. Further complications arise because capital gains not realized before the asset holder's death may escape taxation. Also, much capital gains income is realized by tax-exempt or tax-deferred funds such as pensions or individual retirement accounts. See Auerbach (1983), pp. $919-20$ for further discussion and reterences.
} 
As we can see from equation 10 , the effect of the capital gains personal tax subsidy depends on the ratio $\left(1-\tau_{p}\right) /\left(1-\tau_{t}\right)$. If the personal tax rate on interest income equals the tax rate on capital gains income, this ratio will be unity, and equation 10 gives the same opportunity cost of funds that was derved in the absence of personal tax considerations.

This ratio, however, is not equal to unity. Assuming an average marginal personal tax rate on ordinary income of 28 percent, a 60 percent capital gains exclusion, a 3 percent real after-tax discount rate, and a 10year holding period for longuterm capital gains, the ratio $\left(1-\tau_{p}\right) /\left(1-\tau_{\text {cg }}\right)$ was 0.78 for the old tax law. This figure is based on an effective capital gains tax rate of 8.3 percent from equation 12 . Removing the 60 percent capital gains exclusion and lowering the personal tax rate to 22 percent gives an effective capital gains tax rate of 16.4 percent and a ratio $\left(1-\tau_{p}\right) /\left(1-\tau_{\mathrm{cg}}\right)$ of 0.93 for the new tax law.

Under a completely neutral tax system, all personal income would be taxed equivalently; so $\left(1-\tau_{p}\right) /\left(1-\tau_{c s}\right)$ would equal unity. Thus, tax reform moves the system toward neutrality from this perspective alone.

\section{TAX REFORM AND EFFICIENCY: AN OVERALL ASSESSMENT}

The preceding sections of this article analyzed a number of non-neutral features of U.S. capital taxation. The effect of tax reform on each of these nonneutralities was considered separately. This section provides an overall assessment of whether tax reform has brought capital faxation closer to the efficiency standard.

Table 2 provides one perspective on the efficiency of the tax law, before and after tax reform. The figures show the ratio of the actual after-tax cost of capital to the efficient cost of capital under neutral taxation. The calculations are based on the assumption that the real interest rate firms face in the market reflects the social opportunity cost of providing capital. ${ }^{26}$ Thus, this ratio

\footnotetext{
25 These results were not changed much by increasing the real, after. tax discount rate to 5 percent, or shortening the holding period to 5 years. With the maximum marginal personal tax rates, however, greater subsidies result. The $\left(1-\tau_{\mathrm{p}}\right) /\left(1-\tau_{\mathrm{cg}}\right)$ ratio was 0.59 for the old law and 0.89 for the new law.

${ }^{26}$ This ratio is computed as the actual cost of capital from equation 11 , $(1-k-\tau z)\left(c-\pi_{e}+d\right)$, where $c$ is defined in equation 10 , to the cost of capital under neutral taxation from the right side of equation 5 , $(1-\tau)(i+d)$. The investment tax credit rates are adjusted to reflect the fact that the depreciation base for an asset eligible for the credit was reduced by onemalf of the credit. Thus, $k=k_{g}(1-0.5 \mathrm{r})$, where $k_{q}$ is the statutory investment tax credit rate.
}

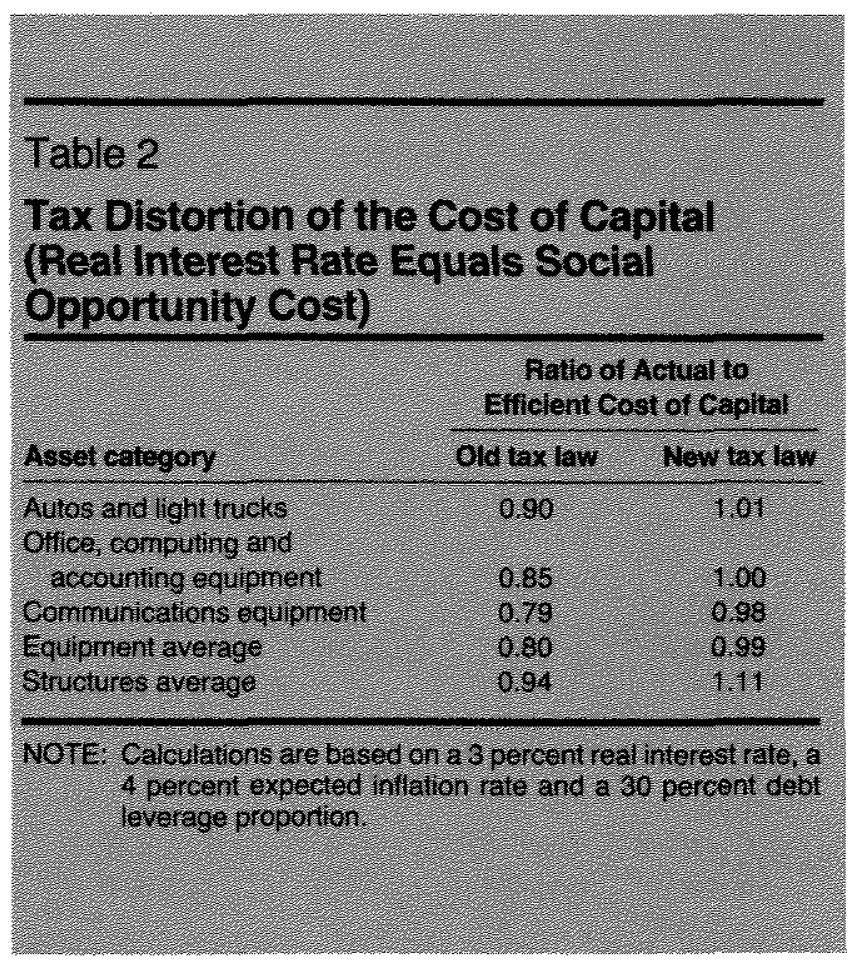

provides a measure of the extent to which the capital taxation system alone distorts investment incentives.

This ratio measures the extent of the tax distortion of capital costs. If the ratio is unity, there is no distortion, and the tax system is neutral for that class of asset. A ratio less than one indicates that the $\operatorname{tax}$ system encourages investment relative to the efficient rate; a ratio greater than one shows that the tax system discourages investment relative to the efficient rate,

The effects of tax reform on equipment tax distor tions are striking. Under the old tax law, the system provided a subsidy to equipment investment: the ratios are less than one. This was due primarily to the investment tax credit. Under the new law, the treatment of equipment approaches remarkably close to tax neutrality. The results presented in table 2 are based on a 3 percent real interest rate, a 4 percent expected inflation rate and a 30 percent marginal debt leverage ratio, Qualitatively similar results for equipment asset classes are obtained for a wide range of assumptions about these parameters.

For business structures, the result appears less favorable. The generous depreciation allowances for structures under the old tax law caused the after-tax cost of capital to fall below the efficient level for structures as well as equipment. By sharply reducing the value of structures' depreciation allowances, however, tax reform pushes the after-tax cost of structures' capital well above the efficient level. 
The excessive taxation of business structures, however, may not be as large as the figures in table 2 suggest. The calculations assume that all investment is financed with the average 30 percent debt leverage ratio. But structure debt leverage ratios are probably higher than the average, because collateral value provided by structures is more easily realized than the values of firm-specific equipment. Higher leverage ratios reduce the cost of capital because interest expense is tax deductible. If the leverage ratio for structures reaches 50 percent to 70 percent (the exact value depends on expected inflation), structures taxation will be neutral, even under the new tax depreciation schedules. ${ }^{27}$

The results presented in table 2 reflect the efficiency of taxes on firms' capital alone because the real market interest rate was assumed to reflect the social opportunity cost of capital. As mentioned earlier, however, individuals pay personal taxes on interest income. Thus, the market interest rate exceeds the return required by savers. Suppose that savers require an after-tax rate of return of $r$. Because nominal interest is taxed, the nominal market interest rate $\left(i+\pi_{e}\right)$ must satisfy:

(13) $\quad r=\left(i+\pi_{e}\right)\left(1-\tau_{p}\right)-\pi_{e}$

to give savers an after-tax real rate of return equal to $\Gamma^{2.3}$

This changes the comparison between the actual and efficient cost of capital in a fundamental way. The efficient cost of capital is based on the social discount rate $r$, while firms must pay a higher real interest rate in the market to compensate savers for the personal taxes they pay on interest income. To reach efficiency according to this perspective, therefore, investment must receive tax subsidies that stimulate capital spending sufficiently to offset the disincentives to saving arising from taxes on personal interest income.

Table 3 presents tax ratios that incorporate this effect. The results are different from those in table 2 for the capital tax system alone. The investment subsidies for equipment in the old tax law led to an effective cost of capital that still fell below the after-fax opportunity

\footnotetext{
27) ft the leverage ratio is thigher than average for structures, it must be lower than average for equipment. For example, a 50 percent structures leverage ratio woutd imply about 20 percent equipment leverage to obtain a weighted average of 30 percent because approximately two-thirds of investment consists of equipment. Reducing the leverage ratio to 20 percent for equipment, however does not substantially change the results presented in this article.

${ }^{28}$ This issue is discussed in detail by Darby (1975) and Feldstein (1976).
}

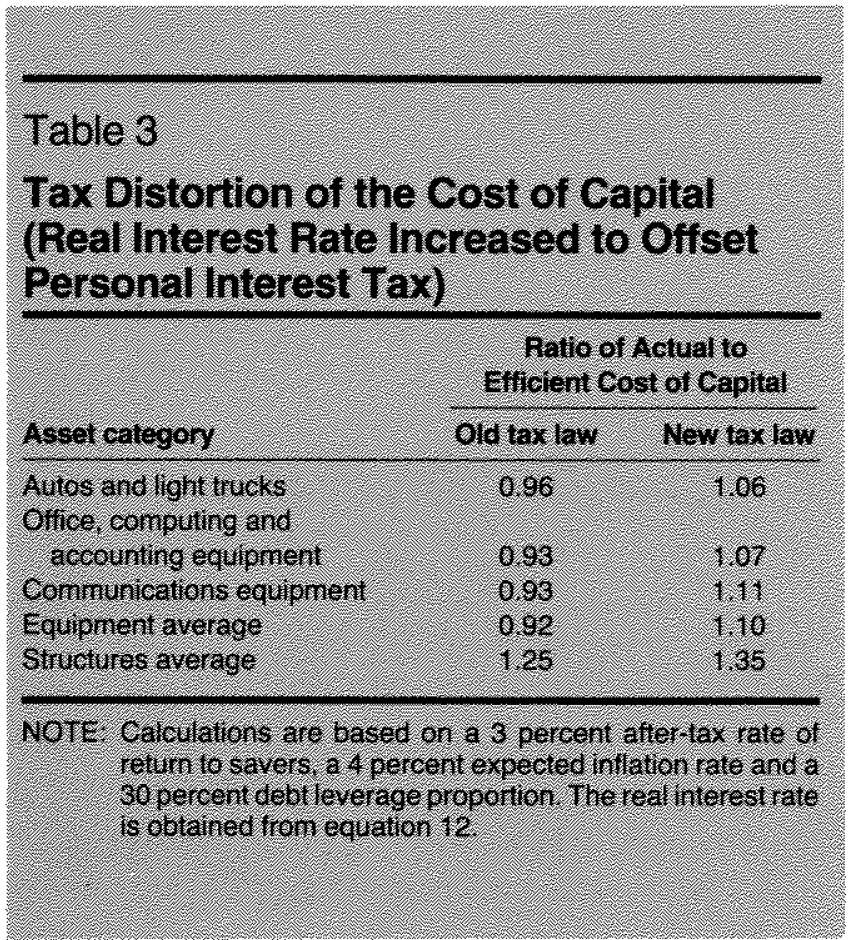

cost of savers, although the tax ratios for the old law in table 3 are closer to unity than in table 2 . The cost of capital for structures that were ineligible for the investment tax credit, however, was well above the efm ficient level, even with the old law's generous depreciation allowance. By removing the capital subsidies, tax reform increased the cost of capital above the efficient level in all cases. To the extent that investment subsidies are desirable to offset the disincentive to saving caused by personal taxes on interest, tax reform does not improve efficiency.

One also should note that the tax distortions for the new law become worse at higher expected inflation rates. This is because personal taxes are levied on nominal interest income. As expected inflation and nominal interest rates rise, therefore, the premium required to maintain individuals' after-tax real return on saving rises even faster.

\section{CONCLUDING REMARKS}

This article has analyzed the effect of the Tax Reform Act of 1986 on the efficiency of U.S. capital formation. The results leave little doubt that the old tax law subsidized equipment investment. Tax reform removed these subsidies, especially the investment tax credit. Now, the tax system causes the after-tax cost of capital to correspond closely to economic depreciation and market rates of interest. Tax reform apparently moves equipment taxation close to neutrality, in 
the sense that the after-tax cost of capital reflects real economic depreciation and real market interest rates. For structures, however, an apparent subsidy due to generous depreciation allowances under the old tax law was more than offset by tax reform. Now the tax on structures is substantially higher than the level consistent with neutrality.

From a broader perspective, however, some investment subsidies were necessary to attain an efficient allocation of resources between consumption and capital formation. Because personal interest income is subject to tax, many economists have argued that the market interest rate overstates the social opportunity cost of investing in capital. Thus, investment subsidies, like those in the old tax law, can offset the disincentive to saving arising from personal taxes.

One might argue that the distortion caused by per sonal taxes on interest income should be dealt with directly rather than by subsidizing capital investment. The lower personal tax rates resulting from tax reform accomplish this to some extent, although this effect is offset by higher taxes on capital gains and tighter restrictions on IRA benefits. Thus, tax reform's implications for the efficient allocation of current resources between investment and consumption remain ambiguous.

\section{REFERENCES}

Aaron, Henry J. "The Impossible Dream Comes True: The New Tax Reform Act," The Brookings Review (Winter 1987), pp. 3-10.

Auerbach, Alan J. "Taxation, Corporate Financial Policy and the Cost of Capital," Joumal of Economic Literature (September 1983), pp. 905-40.
Darby, Michael R. "The Financial and Tax Effects of Monetary Policy on Interest Rates," Economic Inquiry (June 1975), pp. 26676.

Economic Report of the President. (U. S, Government Printing Office, 1987)

Fazzari, Steven M. "Tax Reform and Investment: How Big an Impact?" this Review (January 1987), op. 15-27.

Fazzari, Steven M., and Michael J. Athey. "Asymmetric Information, Financing Constraints, and Investment," Review of Economics and Statistics (forthcoming, 1987).

Fazzari, Steven M., and Jotn P. Caskey. "Macroeconomics and Credit Markets," Journal of Economic issues (June 1986), pp. 42129.

Feldstein, Martin. "Inflation, Income Taxes and the Rate of Interest: A Theoretical Analysis," American Economic Review (December 1976), pp. $809-20$.

Gravelle, Jane G. "Effects of the 1981 Depreciation Revisions on the Taxation of Income from Business Capital." National Tax Journal (February 1982), pp. 1-20.

Hall, Robert, and Dale Jorgenson. "Tax Policy and investment Behavior," American Economic Review (June 1967), pp. 391-414.

Henderson, Yolanda. "Lessons from Federal Reform of Business Taxes," New England Economic Review (November/December 1986), pp. 9-25.

Prakken, Joel L. "The Macroeconomics of Tax Reform," presented at the American Council for Capital Formation conference entitled "The Consumption Tax: A Better Altenative?" September 3-5, 1986, Washington, D.C

Ott, Mack. "Depreciation, Intlation and Investment incentives: The Effects of the Tax Acts of 1981 and 1982," this Review (November 1984), pp. $17-30$. 